\title{
Narasi Kepemimpinan Nani Wartabone Dalam Perjuangan Kemerdekaan Indonesia Di Gorontalo untuk Penguatan Karakter Siswa SMA
}

\author{
Ferrari Yuliawati Samsudin \\ Universitas Sebelas Maret \\ ferrariyuliawati@student.uns.ac.id
}

\section{Article History}

received $1 / 9 / 2021$

revised $1 / 10 / 2021$

accepted 1/11/2021

\begin{abstract}
Gorontalo is one of the provinces located on the island of Sulawesi, at that time Gorontalo was still part of North Sulawesi but they decided to separate and create a new province. This paper describes how a son of Gorontalo was able to show his sense of nationalism and leadership towards the struggle for Indonesian independence, especially in pre-independence times in Gorontalo. Nani Wartabone is now a national hero. Nani Wartabone is the son of Gorontalo who began actively fighting for Indonesia since junior high school and he also worked a lot of leadership in the field of politics, social, education and economy. The method used in this writing is the study of literature from journals and books relevant to this article. The purpose of this literature review is to explore further the leadership of Nani Wartabone. From the results of this literature study can be drawn conclusions where the leadership attitude of Nani Wartabone can be used as a suri tauladan for high school students as a booster of leadership character in the future.
\end{abstract}

Keywords: Leadership, Nani Wartabone, Strengthening Student Character

\begin{abstract}
Abstrak
Gorontalo adalah salah satu provinsi yang terletak dipulau Sulawesi, pada waktu itu Gorontalo masih bagian dari Sulawesi Utara tetapi mereka memutuskan untuk berpisah dan membuat provinsi baru. Tulisan ini menggambarkan bagaimana seorang putra Gorontalo mampu memperlihatkan rasa nasionalisme serta kepemimpinannya terhadap perjuangan kemerdekaan Indonesia khususnya pada zaman pra-kemerdekaan di Gorontalo. la adalah Nani Wartabone yang sekarang sudah menjadi pahlawan nasional. Nani Wartabone ini adalah putra Gorontalo yang mulai aktif memperjuangkan Indonesia sejak SMP dan beliau pula banyak menepakkan kiprah kepemimpinan perjuangannya pada dibidang politik, sosial, pendidikan serta ekonomi. Metode yang digunakan pada penulisan ini adalah kajian literatur dari jurnal-jurnal serta buku buku yang relevan dengan tulisan ini. Tujuannya kajian literatur ini untuk mengeksplor lebih jauh tentang kepemimpinan Nani Wartabone. Dari hasil kajian literatur ini dapat ditarik kesimpulan dimana sikap kepemimpinan dari Nani Wartabone ini dapat dijadikan suri tauladan bagi siswa/i SMA sebagai penguat karakter kepemimpinan dimasa yang akan datang.
\end{abstract}

Kata kunci: Kepemimpinan, Nani Wartabone, Penguatan Karakter Siswa

Social, Humanities, and Education Studies (SHEs): Conference Series https://jurnal.uns.ac.id/shes

p-ISSN 2620-9284

e-ISSN 2620-9292 


\section{PENDAHULUAN}

Kepemimpinan (leadership) berasal dari memipin (lead). Lead berasal dari bahasa Anglo Saxon yang artinya jalur perjalanan kapal yang mengarahkan awak kapal. Arinya pemipin kapal (nahkoda) harus mampu mengarahkan kapal sebagai wadah organisasi dan mengarahkan awak kapal sebagai pengikut (bawahan) untuk mencapai tujuan bersama yang telah ditetapkan. Bush (2008:44) menyatakan bahwa pemimpin adalah orang yang menentukkan tujuan, memotivasi, dan menindak pengikutnya. Tugas utama pemimpian adalah menginspirasi pengikutnya agar berkomitmen kepada pemimpinnya sebagai organisasi. Komitmen adalah lebihmengutamakan kepentingan orang banyak daripada kepentingan pribadi (Husain Usman.2019:3).

Dalam antropologi budaya, muncul pandangan yang memberdakan antara kepemimpinan sebagai suatu kedudukan sosial sebagai suatu protes sosial (Koentjaningrat:1969). Kepemimpinan sebagai kedudukan sosial merupakan kompleks dari hak-hak dan kewajiban-kewajiban yang dapat dimiiliki oleh seseorang.

Semua orang terlahir menjadi pemimpin tetapi bagaimana caranya indovidu itu sendiri menjadikan dirinya sebagai pemimpin. Banyak hal yang dapat dilakukan untuk menjadi seorang pemimpin yakni dengan cara mengontrol diri sendiri dari sifat yang tidak diinginkan dan dapat merugikan, itu juga sudah dapat dikatakan sebagai pemimpin. Hal lain dengan ruang lingkup yang lebih luas lagi. Pada setiap negara sudah pasti membutuhkan yang namanya sebuah pemimpin, misalkan seperti presiden. Kita ketahui bersama bahwasannya Indonesia adalah negara yang pada zaman dahulunya adalah negara yang pernah dijajah beberapa negara luar dengan mengatas namakan silaturahmi tetapi tidak demikian dengan realitanya. Tujuan pertama yaitu bersilaturahmi (berlayar) sudah terlaksana tetapi makin kesini makin menjadi jadi tindak kesesewenangan terhadap rakyat pribumi. Otomatis pada situasi pada saat itu sudah pasti negara itu membutuhkan seorang pemimpin yang mempunyai jiwa kepempinan yang tinggi serta jiwa nasionalisme yang melekat pada dirinya yaitu seorang pahlawan. Berhubung Indonesia adalah negara yang luas dari Sabang hingga Marauke beberapa pulau, suku, agama maupun ras, sehinggnya pada setiap pulau atau daerah memiliki seseorang yang dianggap sebagai orang yang dapat memipin penjajahan terhadap wilayahnya masing-masing.

Menurut Kamawati dan Zainudin (2014) dalam penelitiannya bahwa pendidikan karakter sebagai pendidikan nilai, pendidikan pengaturan, pendidikan moral dan pendidikan disposisi untuk mengembangkan kemampuan siswa untuk memutuskan, mengurus dan membuat kebaikan. Menurut Battisch (2009) Pendidikan karakter adalah sesuatu yang disengaja menggunakan semua dimensi kehidupan sekolah untuk mendorong pengembangan karakter yang optimal.

Dalam pembelajaran sejarah juga secara tidak langsung mengajarkan bagaimana menjadikan seseorang menjadi pemimpin yang baik dan cermat serta kepemimpinan nya itu dapat menjadi suri tauladan para siswa masa kini. Karna yang diketahui pembelajaran sejarah ialah menitik beratkan pada 3 periodisasi waktu yang dapat dijadikan patokan yaitu masa lalu, masa kini, masa depan. Sehinggnya seorang pemimpin sudah mempelajari seluk belutnya dimasa lalu untuk melanjutkannya di masa kini dan masa depan.

\section{METODE}

Berdasarkan konteks permasalahan yang diambil sesuai dengan narasi yang dituliskan dan dijelaskan yang dikaji peneliti menggunakan kajian literatur menggunakan metode kualitatif. Dengan menggunakan metode ini yaitu mendeskrpsikan suatu analisis fenomena, sikap, persepsi pemikiran orang secara individual maupun kelompok. 
Penelitian ini di objekkan di Gorontalo karena subjek yang diambil peneliti ialah mendeksripsikan suatu pahlawan nasional Indonesia. Metoode yang digunakan riset Pustaka sekaligus memanfaatkan sumber perpustakaan untuk memperoleh data penelitannya. Riset Pustaka tentu saja tidak hanya sekedar urusan membaca dan mencatat literatur atau buku-buku, melainkan serangkaian kegiatan yang berkenaan dengan metode pengumpulan data Pustaka, membaca, mencatat serta mengolah bahan penelitian.

\section{Biografi Nani Wartabone}

\section{HASIL DAN PEMBAHASAN}

Pada tanggal 30 April 1907 tepatnya di desa Suwawa lahirlah seorang putra dari keluarga yang masih keturunan raja atau pengesuasa di Suwawa, ayahnya bernama Zakirah Wartabone dan Saerah Mooduto. Nani Wartabone mengikuti Pendidikan, pada awal Pendidikan di SD di Suwawa dan dilanjutkan ke HIS (Holland Inslaach School) setelah tamat dari HIS, Nani Wartabone ke Surabaya masuk ELS ( Europesch Lagere School) kemudian ia melanjutkan tingkat selanjtunya di Mulo (Meer Uitgebreid Lagere Oderwijs) di Tondano tapi saying di sekolah itu ia tidak menamatkannya karena pindah di Surabaya kemudian menamatkan pendidikannya di Surabaya. Setelah menyelasikan pendidikkannya Nani memilih Kembali ke Gorontalo untuk mengabdikkan hidupnya Bersama-sama dengan masyrakat tani, sebagaimana kebiasaan dan kesukannya sejak kecil.

Nani Wartabone cukup banyak melalang buana pada semasa menempuh pendidikannya. Dari sekolah pribumi sampai sekolah milik Belanda ia pernah jalani hanya untuk mendapatkan banyak ilmu dan banyak pemahaman tentang dunia luar serta tentang perpolitikan yang dapat diimplikasikkan di daerahnya sendiri. Munculnya rasa nasionalisme Nani pada waktu itu memang ada beberapa kejidian yang ia alami selama belajar di Surabaya dari ketidak adilan para guru serta bagaimana sikap teman-teman yang tercampur dari berbagai negara yang memang notabenenya kaum putih yaitu Cina,Belanda dan anak Indpnesia lainnya yang memang bagian kasta tertinggi.

Sehingga Nani pada suatu masa mendenagrkan berbagai ceramah yang sering disampaikan mendapatkan landasan nasionalisme dalam memperjuangkan kemerdekaan. Kekagumannya terhadap Sokarno membawanya pada kesempatan untuk tinggal di rumah beliau dan dimanafaatkan secara baik oleh Nani entah itu membaca buku-buku politk, diskusi dengan Soekarno sehingga mulai dari situ Nani tergerak hatinya dengan prinsip harus memperjuangkan bangsanya sendiri yaitu menjadi suatu pemimpin diwilayah asalnya yaitu Gorontalo.

Nani Wartabone akhirnya meninggal dunia pada tanggal 3 Januari 1986 dan dikebumikkan di daerah Suwawa. Acara pemakaman Nani Wartabone dilaksnakan dengan upacara militer. Saat itu gubernur Sulawesi Utara bertindak sebagai inspektur upacara.

\section{Awal Pergerakan Nani Wartabone di Gorontalo}

Pada tahun 1931 Nani Wartabone mendirikian Cabang Partai Indonesia Raya (Partindo) di Gorontalo yang diketuai dengan Nani Wartabone sendiri. Dalam pergerakan partai ini Kolonial Belanda berusaha menghalangi dan membatasi kegiatan dengan Partindonya seperti mengadakan rapat umum yang dianggap menghasut rakyat untuk menuntut Indonesia merdeka. Pihak Kolonial Belanda juga berupaya membujuk Nani Wartabone bersedia menjadi pegawai pemerintah dengan gaji yang besar. Namun permintaan itu ditolak mentah-mentah oleh Nani. Sejak Pemerintah Kolonial Belanda mulai melarang kegiatan Partindo diseluruh Indonesia tahun 1933, Nani mengalihkan perjuangannya melalui organisasi social seperti Muhammadiyah. 
Sudah jelas terlihat kepemimpinan Nani Wartabone diawal masa pergerakan untuk mengusir Kolonial Belanda. Seakan-akan Nani tidak habis akal untuk bagaimana tetap menjalankan misi memerdekan Indonesia. Dari membuat partai politik yaitu Partindo tetapi Kolonial Belanda mulai melarang di seluruh Indonesia karena memang ketakutan Kolonial Belanda terhadap masyrakat terhasut doktrin kuat yang dilancarkan Nani Wartabone, dalam pembahtasan Partindo itu juga pihak Kolonial Belanda sempat merayu Nani bahawasannya diiming-imingi gaji yang besar untuk menjadi staf pegawai pemerintah Kolonial namun rayuan Kolonial Belanda tidak sama sekali berhasil karena memang Nani Wartabone sudah berpegang erat prinsip nya yaitu dalam perjuangannya bersifat non kooperatif. Tidak habis disitu akal seorang Nani Wartabone ditutup organisasi politiknya ia beralih ke organisasi social seperti Muhammadiyah. Karena hal ini Nani Wartabone berpikir bahwa dapat lebih gampang melancarkan tujuannya, dengan begitu organ social yang dijalankan tetap saja Nani Wartabone mengeluarkan ideide politiknya untuk mewujudkan tujuannya yaitu memerdekan kemerdekaan Indonesia.

Kekhasan sejarah dan kebudayaan masyarakatnya menjadikan Gorontalo harus berhadapan dengan Pemerintah Daerah Tingkat I Sulawesi Utara yang didominasi etnis Minahasa maupun Pemerintah Pusat yang didominasi etnis Jawa terutama pada era reformasi. Secara historis, di satu pihak Gorontalo memiliki catatan sejarah yang panjang tentang perlawanan terhadap Belanda dan bahkan telah menunjukkan upaya integrasi yang kuat dengan wilayah Indonesia lainnya. Kuatnya integrasi ini disebabkan karena pada masa kolonial masyarakat Gorontalo telah berhubungan dengan organisasiorganisasi nasionalis berbagai daerah lain di Nusantara.

Sejarah Panjang yang dimiliki masyrakat Gorontalo terhadap persoalan penjajahan terhadap Belanda ini mempunyai dukungan kuat dari beberapa wilayah yang sudah Nani bangun dengan cara berhubungan baik dengan organisasi nasional diberbagai Nusantara sehingganya jelas pergerakan yang di Pimpin oleh Nani Wartabone mendapat dukungan dari banyak pihak dan banyak massyrrakat pribumi Gorontalo yang saling bahu membahu untuk melancarkan tujuan Indonesia untuk merdeka.

Wilayah Gorontalo saat itu masih bersifat administrative temasuk dalam wilayah Kresidenan Manado, juga menerima implikasi dari kebijakan polit etis yang direncanakan Belanda. Pada waktu itu kemunculan tokoh-tokoh nasionalis ditanah Jawa yang menjadi pusat modernisasi saat itu saat itu seperti Moh.Hatta, Soekarno dan sebagainya, diikuti oleh kemuncullan tokoh-tokohh local yaitu Nani Wartabone .

Dalam abad 20 Gorontalo belum sepenuhnya menjadi provinsi tersendiri melainkan masih bergabung dengan Manado. Ternyata pergerakan ini tidak hanya sendiri dari perlawanan masyrakat Gorontalo saja melainkan tokoh nasionalis dari luar Gorontalo seperti Jawa bergabung ikut serta dalam pergerakan ini yang dengan implikasi politik etis ini.

\section{Peristiwa 23 Januari 1942}

Peristiwa pengambil alihan kekuasaan dari Pemerintah Kolonial Belanda di Gorontalo dikenal dengan peristiwa 23 Januari 1942 merupakan fase penting dalam perjalanan sejarah Gorontalo. Gorontalo yang terletak bagian utara pulau Sulawesi merupakan salah satu pintu masuk Jepang dalam investasinya ke wilayah HindiaBelanda. Kepanikan Pemerintah Belanda dalam menghadapi kekuatan Jepang kekuatan Jepang direspon dengan pengambilan alih kekuasaan oleh Nani Wartabone. Pada saat peristiwa 23 Januari 1942 berlangsung Belanda telah lemah sebab beberapa pasukan dutarik ke wilayah Poso (Sulawesi Tengah). Pada saat pelemahan ini lah diambil kesempatan oleh Nani Wartabone untuk mengambil alih kekuasaan.

Peristiwa 23 Januari 1942 yang jatuh pada hari Jumat bukan hanya sekedar tanggal yang disematkan untuk hal biasa, tetapi tanggal dan bulan ini bermakna 
mendalam bagi rakyat Gorontalo yang dapat sedikit demi sedikit perjuangan untuk mencapai kemerdekaan.

Pada athun 1940, Nani Wartabone mempersiapkan beberapa pasukan yang dihadiri pemuda berjumlah sekitar 575 dipusatkan di Mono arah Pinogu untuk persiapan merebut kekuasaan dari tangan Belanda di Gorontalo, dan pertengahan itu mendapat informasi bahawasannya rencana Belanda akan membumi hanguskan Gorontalo. Menyikapi hal tersebut Nani langsng melontarkan ancaman dan mengkoordinir pasukkan untuk mempengaruhi diseritai dengan ancaman dan membawakan hasil mereka banyak bersedia bergabung dengan pasukan Nani Wartabone.

Pasukkan yang dipusatkan di Pinogu ini terdiri dari campuran beberapa kaum entah orang tua dan pemuda. Dalam melancarkan rencananya Belanda mengancam akan membumihanguskan Gorontalo tetapi sikap kepemimpinan Nani Wartabone langsung sigap dengan hal tersebut bahkan pada waktu itu Juga Nani langsung mengkoordinir dan mempengaruhi rakyat lainnya untuk bergabung dalam rangka menggagalkan rencana pengbumihangusan Gorontalo. Pasukan yang dapat dipengaruhi oleh Nani Wartabone berasal dari pemuda Gorontalo, orang tua, orang Minahasa dan Pande Kalengkongan yang siap bergabung .

Setelah berhasil penangkapan tersebut sejumlah pejabat Pemeriintah Kolonial Belanda dan melecuti senjata mereka maka bertuliskan Indonesia berpalemen untuk pertama kali dipancangkan di depan dinding Kantor pos Gorontalo, sementara itu bendera Belanda yang telah dirobek oleh Nani Wartabone sehingga menjadi Merah Putih juga di pancangkan di halaman Kantor Keresiden Belanda di Gorontalo.

Dalam hal ini Nani Wartabone sangat bersyukur atas solidaritas serta dukungan kepada rakyat Gorontalo maupun dari Minahasa dan selebihnya telah mencapai titik ini dengan penuh drama panjang yang tidak akan bisa jalankan sendiri tanpa ada dukungan dari rakyat local itu sendiri, pada hal ini Nani Wartabone berpidatoo di alunalun didepan massa rakyat Gorontalo yang menyaksikkan sejarah panjang ini.

Isi pidato Nani Wartabone tersebut di atas memperlihatkan bahwa meskipun bangsa Indonesia secara keseluruhan masih harus menunggu kurang lebih tiga tahun lagi untuk memproklamirkan kemerdekaannya, namun rakyat di Gorontalo seolah-olah telah bangkit mewakili bangsanya untuk lepas dari penjajahan. Isi pidato tersebut juga memperlihatkan bahwa loyalitas rakyat Gorontalo terhadap Negara Kesatuan Republik Indonesia (NKRI) tidak diragukan lagi. Setelah memproklamirkan kemerdekaan, kemudian para pejuang kemerdekaan Gorontalo pun langsung membentuk Pucuk Pimpinan Pemerintah Gorontalo (PPPG) hingga masuknya Jepang di daerah itu . Adanya Pucuk Pimpinan Pemerintah Gorontalo tersebut melambangkan bahwa pemerintahan kolonial telah diambil alih oleh bangsa yang memang berhak menjadi penguasa di daerahnya sendiri.

Nani Wartabone dilepaskan Jepang pada 6 Juni 1945. Setelah menyerah kepada sekutu, Jepang menyerahkan pemerintah Gorontalo kepada Nani Wartabone. Pada 1 september 1945 Nani Waetabone membentuk Dewan Nasional di Gorontalo sebagai badan legislative untuk mendampingi kepala pemerintahan. Pada 30 November 1945, sekutu menangkap Nani Wartabone di pindah-pindah ke Morotai, Maluku Utara lalu ke Cipinang. Beliau akhirnya dibebaskan pada 23 Januari 1949 setelah pengakuan kedaulatan Indonesia.

Nani Wartabone menentang bentuk pemerintahan Republik Indonesia Serikat (RID) yang ada pada saat itu. Saat terjadi \{RRI/Permesta, Nani Wartabone membantu tentara membeaskan Gorontalo dari kekuatan pemberontak. Selanjutnya Nani Wartabone dipercaya mengemban beberapa jabatan penting diantaranya Residen Gorontalo, anggota DPD Sulawesi Utara, aggota MPRS RI, anggota Dewam Perencang Nasional dan anggota DPA. Pada tanggal 3 Januari 1986 sebagai sorang petani di desa terpencil, Suwawa Gorontalo. Pada 6 November 2003 berdasarkan 
Keppres No.085/TK/2003, Pemerintah menobatkan Nani Wartabone sebagai pahlawan (Didi Junaedi.2014:148).

\section{Penguatan Karakter Slswa}

Penguatan karakter yang ada didalam siswa berlandaskan falsafah Pancasila maknanya setiap aspek karakter harus dijiwai oleh kelima sila Pancasila secara utuh dan komperensif. Berbangsa yang berketuhanan maha Esa merupakan awal dasar akhlak manusia yang harus dipegang teguh sesuai ajaran dan agamanya masingmasing. Dalam penguatan karakter siswa juga bukan hanya dapat menjadikan suri tauladan orang lain melainkan berketuhanan siswa dapat kenal lebih jauh siapa dirinya ini dan perilaku iman takwa serta akhlak sebagai karakteristk pribadi bangsa Indoensia. Bangsa berperimanusiaan yang adil dan beradab, dalam mewujudkan siswa/i yang berkrprimanusiaan adil dan beradab ini timbul rasa saling memiliki satu sama lain dan menimbulkan rasa saling hormat menghormati. Dengan adanya sila kedua ini siswa/i saling bergotong royong menciptakan kekeluargaan antar manusia yang mencerminkan rasa peduli dan rasa saling mempunyai satu kesatuan.

Bangsa mengedepankan persatuan dan kesatuan bangsa, perlu diketahui bersama bahwa komitmen perilaku yang slalu mengutamakan kesatuan Indoensia diatas kepentingan pribadi, kelompok dan golongan. Siswa/i bisa menjadikkan suatu banyaknya pahlawan Indonesia yang dimana sikap mereka mengedepankan kesatuan dan keutuhan bangsanya dengan mengikuti beberapa perlawanan untuk Indonesia merdeka pada waktu itu, tetapi kini sudah tidak lagi. Siswa/i pada saat ini bisa mengambil pelajaran serta pengalaman pahlawan contoh seorang Nani Wartabone yang tidak ada bayangan pada masa kecilnya dapat menjadi beberapa pemipin untuk masalah besar yang sedang dihadapi bangsa Indonesia tetapi dengan kekegigihannya ia mampu mewujudkan itu semua.

Bangsa yang menjujung tinggi hukum dan hak asasi manusia, sikap demokratis apabila sudah tertanam pada karakter siswa/i bisa diperkuat Kembali dengan nilai dan semangat kebhinekaan yang dipimpin oleh kebijaksanaan yang dapat dijadikan pelajaran serta pengalaman. Tidak memaksakan kehendak atas nama minoritas sudah mampu dikatakan sebagai perduli dengan hak orang lain. Berbangsa dengan keadilan sosial bagi seluruh Indonesia, dalam sila terkahir ini sudah bisa di kutipkan bahwasannya Indonesia adalah negara besar yang memiliki banyak pulau, Bahasa,ras,suku,agama sehingganya ketoleransian yang diutamakan dan tidak saling menghardik satu sama lain apalagi menimbulkan saling ketidak nyamanan satu sama lain.

\section{SIMPULAN}

Semua orang terlahir menjadi pemimpin tetapi bagaimana caranya indovidu itu sendiri menjadikan dirinya sebagai pemimpin. Banyak hal yang dapat dilakukan untuk menjadi seorang pemimpin yakni dengan cara mengontrol diri sendiri dari sifat yang tidak diinginkan dan dapat merugikan, itu juga sudah dapat dikatakan sebagai pemimpin. Hal lain dengan ruang lingkup yang lebih luas lagi. Pada setiap negara sudah pasti membutuhkan yang namanya sebuah pemimpin,

Seseorang bisa dikatakan berhasil mempipin apabila mempunyai masa, mempunyai rasa kepemimpinan yang kuat dan rasa bertanggung jawab atas apa yang dipimpinnya. Dari narasi Nani Wartabone banyak sekali pengalaman serta pelajaran yang dapat diambil untuk memperkuat Pendidikan karakter seorang siswa/i. Pelajaran dari seorang Nani Wartabone tidak hanya pelajaran masa lalu yang dapat diambil melainkan untuk sisi masa depan dan masa kini nya juga bisa. Intinya ketika sudah mempunyai mimpi yang besar dan terpuji kerjakan dengan sepenuh hati niscaya kemudahan selalu teriring untuk orang yang mau berusaha dan mencoba. 


\section{DAFTAR PUSTAKA}

Didi Junaedi. 2014. Pahlawan-pahlawan Indonesia Sepanjang Masa. Indonesia Tera: Yogyakarta.

Doni Koesoema A. 2007. Pendidikan Karakter. PT Grasindo: Jakarta.

Edwin Mirza Chaerulsyah. 2014. Persepsi Siswa Tentang Keteladanan Pahlawan Nasional Untuk Meningkatkan Semangat Kebangsaan Melalui Pembelajaran Sejarah Di SMA Negeri 4 Kota Tegal TA. 2012/2013. Seminar Nasional. ISBN:978-602-7561-89-2.

Herwulan Irine Purnama. 2019. Penguatan Pendidikan Karakter Berbasis Budaya Literasi Dasar. Yudha English Gallery: Kalimantan Barat.

Husaini Usman. 2019. Kepemimpinan Efektif Teori, Penelitian, dan Praktik. PT Bumi Aksara: Jakarta Timur.

Kartini Kartono. 2006. Pemimpin dan Kepemimpinan. Apakah Kepemimpinan abnormal itu?. PT RajaGrafindo: Jakarta.

Mahyudin Damis. 2019. Daerah Gorontalo Dalam Perubahan Politik Nasional. Jurnal Holistik, Vol.12/April-Juni.

Mansur. 2004. Biografi Pahlawan Nasional Hj.Nani Wartanone. Departemen Sosial RI Direktorat Jenderal Pemberdayaan Sosial Direktorat Kepahlawanan, Keperintisan Dan Kejuangan: Jakarta.

Mestika Zed. 2008. Metode Penelitian Kepustakaan. Yayasan Obor Indonesia: Jakarta.

Muh. Baehaqi. 2020. Katalog Dalam Terbitan (KDT) Perpustakaan Nasional Republik Indonesia Pendidikan Nasionalisme Usman Mafrukhin. CV Pilar Nusantara: Semarang.

Mursalat Kulap.2017. Nani Wartabone dalam Pergerakan Nasional di Gorontalo. Oase Pustaka: Mojolaban Sukoharjo.

Reimind Napitupulu, Dkk. 2019. Dasar-Dasar Ilmu Kepemimpinan dan Teori. Uwais Inspirasi Indonesia: Jawa Timur

Rendy Adiwilaga. 2018. Kepemimpinan Pemerintah Indonesia (Teori dan Prakteknya). Deepbulish (CV Budi Utama): Yogyakarta

Ujang Syarip Hidayat. 2019. Penguatan Pendidikan Karaktr Berbass Kearifan Lokal. Budi Mulia: Sukabumi 